\title{
A Evaluation on the Product and Brand Management at Karlo Automobiles(P) Ltd, Patna
}

\author{
Gowtham Aashirvad Kumar,A.Ravikumar,Indhumathi.
}

\begin{abstract}
Product line must know the wants and needs of the client with regard to both the services or products of MARUTI.To assess the understanding of the channels and how they work.To understand whether the client receives the goods and services on time.Planning for better channeling and product improvement The study enables to know the best product possible.To discover the multiple variables that cause discontent to the client, and to overcome them with better strtegy. Channel the allocation that will make it possible to achieve and communicate to the client.This research expands its focus to the research of multiple financial, social and social aspects; geographical, and Political aspects of trade relation between India and the gulf countries.

Keywords :Automobiles,Brand management..
\end{abstract}

\section{INTRODUCTION}

Product executives is an administrative life-cycle feature within a company engaged in the planning or predicting or advertising of a item or brand at all phases of the commodity lifecycle..

Product executives and marketing are distinct but supplementary attempts with the aim of optimizing sales profits, profit margins and profitability. The function of product management extends from strategic to tactical operations and differs depending on the organizational structure of the business. Product procurement can be a distinct feature on its own and a advertising or technology partner.[1-10]

While engaged with the full product lifespan, the primary focus of sales and marketing is on guiding the creation of fresh products. As per the Business intelligence and Management Association (PDMA), exceptional and distinguished fresh products - one that delivers distinctive advantages and positive value to the client - are the prime one driver of achievement and productivity of the brand.

Product governance often plays an integrated role, trying to bridge gaps within the organization among teams of distinct skills, most particularly between design-oriented teams and industry-oriented teams. For instance, product managers often translate the company goals set for a product into engineering specifications through marketing or sales. Conversely they may work to explain the capabilities and limitations of the finished product back to Marketing and Sales. [11-15]Product Managers may also have one or more direct reports such as a Product Executive who can manage operational tasks or a Change Manager who can oversee new initiatives

Revised Manuscript Received on July 22, 2019.

Gowtham Aashirvad Kumar Department of Management studies,Bharath Institute of Higher Education and Research,Chennai,India A.Ravikumar, Department of Management studies,Bharath Institute of Higher Education and Research,Chennai,India

Indhumathi., Department of Management studies,Bharath Institute of Higher Education and Research,Chennai,India

\section{Brand management}

The identification of a particular product, service or company is a trademark. Brands can take many forms, along with names, signs, symbols, color combinations or slogans. The term brand started merely as a means to say one person's cattle to someone else by means of a warm iron stamp. A legally protected brand name is referred to as a brand name. The term brand has developed to incorporate identity-it impacts identity personality of a product, company or service.

A concept product is a brand connected with an abstract concept, such as breast cancer awareness or environmental activism, rather than a particular product, service or business. Acommodity brand is a brand connected with a resource. Have you got milk? It's an instance of a com[16-18]

\section{II.STSTEMENT OF PROBLEM}

Brand and Business development is regarded to be the most significant factor as it includes Customer acquisition and generates brand recognition. The typical components that comprise Customer behavior are: Customer nature, attitude, community, living ....... etc. This research seeks to identify the user experience design of MARUTI SUZUKI goods and services.

\section{OBJECTIVES OF THE STUDY}

The following goals of the research $\bullet$ To discover the finest Maruti Suzuki brand in bihar.

-To understand the significance of four wheelers, i.e. MARUTI SUZUKI, in our daily lives.

-To analyze the factor that influences the use and purchase of MARUTI SUZUKI.

-Identifying the problems of Maruti Suzuki's products and services.

\section{IV.LIMITATIONS OF THE STUDY}

The Following are the Limitations of the study

- Due to absence of time, I have not been able to fulfill the observation of various tasks and documents concerning the organisation.

- Most companies are unwilling to reveal their private information about their sales promotion operations and the upcoming Add Campaigns.

- Highly advanced technology products themselves become a constraint in sales

Promotion where the customer can not comprehend the technical terms and conditions and their benefits.

- Quite often the researcher has to face intransigent people who have Harp as their own tune.[19-27] 
- Non skilled drivers or customers mismanage cars and, for any kind of fault or unhappiness, not only vilify the institution, but also misguide the Upcoming customers.

\section{RESEARCH METHODOLOGY}

\section{RESEARCH}

An examination philosophy characterize, the motivation behind research, how it continue, how to Measure advance and what comprise accomplishment as for the target decided for completing exploration study. The proper research configuration define is point by point underneath:

- Exploratory research : This sort of research has an essential goal of improvement Insights into the issue. It thinks about the fundamental zones where the issue falsehoods and furthermore attempts to assess some suitable strategy.

- The examination strategy for present investigation has been received to mirror those reality and help arrive at the obvious end result in a goal and logical way.

The present examination mulled over an exploratory research Nature of data

Secondary data: Secondary information that is now accessible and distributed. It could be inward or outside wellspring of information. [28]

-Internal sourse: Which start from the particular field or zone where

research Is done. Eg-open broacher, official report ,,,,etc. Information COLLECTION

- Secondary information has been utilized which is gathered through article, reports, diaries, Magazines, papers, report displayed by researchers, colleges and web. [29]

\section{TABLE NO. 1}

Table demonstrating the inclination towards the recurrence of the preparation program by the respondents

\begin{tabular}{|l|l|l|}
\hline Options & No. of Respondents & Percentage \\
\hline Weekly & 49 & 41 \\
\hline Monthly & 45 & 38 \\
\hline Quarterly & 17 & 14 \\
\hline Yearly & 9 & 7 \\
\hline TOATL & 120 & 100 \\
\hline
\end{tabular}

INFERENCE: -

$41 \%$ of the respondents prefer to get trained weekly.

FIG.1

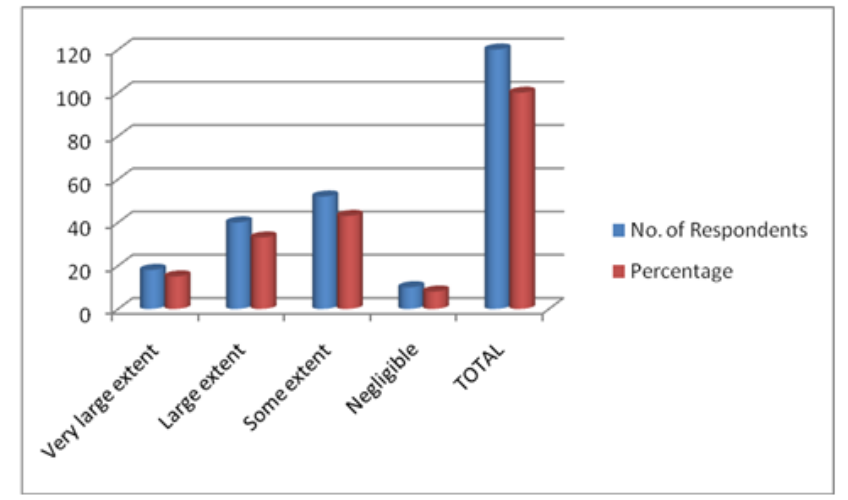

\section{INTERPRETATION:-}

Majority $41 \%$ of the respondents prefer to get trained weekly, $38 \%$ prefer monthly, $14 \%$ of the respondents prefer quarterly training, and only $8 \%$ of them prefer to get trained yearly.

TABLE NO. 2 Table showing the respondents freedom to express their views during the training programme

\begin{tabular}{|l|l|l|}
\hline Options & No. of Respondents & Percentage \\
\hline Very large extent & 18 & 15 \\
\hline Large extent & 40 & 33 \\
\hline Some extent & 52 & 43 \\
\hline Negligible & 10 & 8 \\
\hline TOTAL & 120 & 100 \\
\hline
\end{tabular}

\section{INFERENCE: -}

$43 \%$ of the respondents feel that they are able to express their views during the training programme to some extent.

FIG. 2

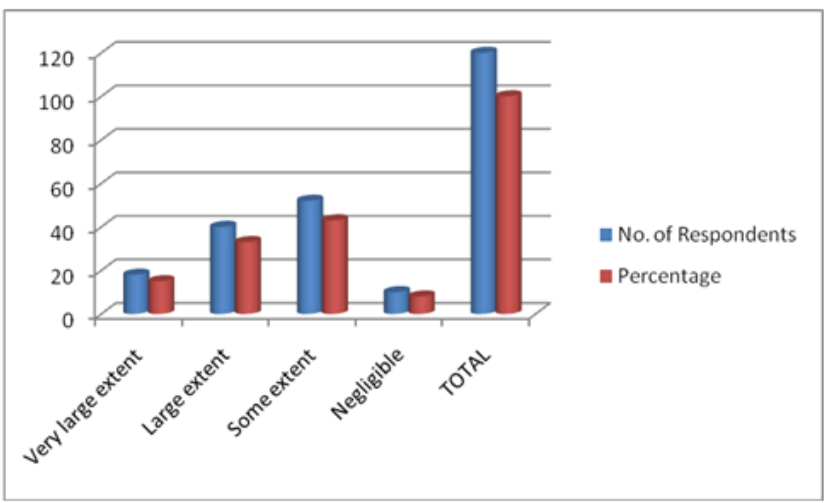

\section{INTERPRETATION:-}

Majority $43 \%$ of the respondents feel that they are able to express their views during the training programme to some extent, $33 \%$ say to large extent, $15 \%$ of the respondents feel that they are able to express their views to a large extent and $8 \%$ of the respondents are left negligible. [30]

\section{V.RESULTS}

Majority $87 \%$ of the respondents are joined to the training programme.

Most $42 \%$ of the respondents are joined to the 6 months training courses.

Mostly $47 \%$ of the respondents wants to do the short term courses.

$\square \quad$ Majority (30\%) of the students are post graduates.

Majority of the respondents are doing the training programme. 
Majority $43 \%$ of the respondents attended the training programme three months back.

Most $44 \%$ of the respondents feel that training is to acquire specific skills and knowledge.

Majority $40 \%$ of the respondents say that the training programme planned was very well.

Most $33 \%$ of the respondents agree that the company take efforts to fulfill their training needs.

Most $38 \%$ of the respondents strongly agree on the opinion that the training helps to achieve the job objectives.

Most $33 \%$ of the respondents are of the view that the training programme was effective in job environment.

Majority $57 \%$ of the respondents are satisfied with the topic covered in the training programme.

Majority $61 \%$ of the respondents prefer joining on the basis of placement.

Majority $80 \%$ of the respondents feels positive about their attitude towards the training programme.

Majority of the respondents gained practical knowledge from the training programme.

Majority $42 \%$ of the respondents prefers to get training programmes in TATA MOTORS

Majority $57 \%$ of the respondents say that trainers in the training programme are immediate supervisor.

Majority $68 \%$ of the respondents prefers internal trainers.[31]

Most $43 \%$ of the respondents are of the view that the communication skills of the trainer in the training programme is highly effective.

Majority $32 \%$ of the respondents are satisfied with the facilitator' s performance.

Majority $41 \%$ of the respondents prefer to get trained weekly.

\section{VI.DISCUSSION}

The organization should conduct training programme for the skills that are identified as training need.

The Tata motors $\mathrm{m}[32]$ ust be advertising our product and company brand name.

The Tata motors has to change the promotional activity.

The organization must be honest about the work and promise because it' $s$ relating to student future.

The organization has to lake of infrastructure and branch. They exceed the branch as possibility.

The training programme can include a session, which enables the student to know latest product and technology.

Company need to design a comprehensive advertisement package to enhance customer awareness.

Company need to develop good industrial tie-ups.

Company need to do price review according to the market condition to take competitor advantage.[33]

\section{VII.CONCLUSION}

Brands succeed when marketers regard them as the result of a well-integrated marketing process.

1. 1. Marketing as naming, designing or marketing is too myopic and will shorten the expected lifespan of the brand.
2. 2. Branding is a flow of information of the appropriate added values for which customers are ready to pay a premium price.

3. It also ensures that the connection with clients is enhanced and extended.

4. 4. Brands originally operated the role of distinguishing between competing products, portraying performance consistency and offering special protection against copying.

\section{REFERENCES}

1) BharthVajan R., Ramachandran S.,Psychographic dimensions of training,2016,International Journal of Pharmacy and Technology,V-8,I-4,P-23727-23729

2) Balakrishnan P., Bharthvajan R.,A study on human resource planning in hospitals in Chennai City,2014,International Journal of Applied Engineering Research,V-9,I-22,P-7503-7507

3) Priyadarsini P., Bharthvajan R.,Role of emotional intelligence training programme in reducing the stress of the nurses,2014,International Journal of Applied Engineering Research,V-9,I-22,P-7411-7421

4) Kerinab Beenu G., Bharthvajan R.,Empirical analysis on the cosmetic buying behavior of young women in South India,2014,International Journal of Applied Engineering Research,V-9,I-22,P-7361-7366

5) Balakrishnan P., Bharthvajan R.,Whistling in the wind,2014,International Journal of Applied Engineering Research,V-9,I-22,P-7586-7593

6) Krishnan B., Peter M.,Health hazards of Indian Bpo employee-an alarming issue,2014,International Journal of Applied Engineering Research,V-9,I-22,P-7336-7341

7) Kerinab Beenu G.H., Peter M.,Role of insurance in economic development,2014,International Journal of Applied Engineering Research,V-9,I-22,P-7532-7539

8) Balakrishnan P., Peter M., Priyadarsini P.,Efficiency of safety measures for wellbeing of employees in manufacturing industry,2014,International Journal of Applied Engineering Research,V-9,I-22,P-7376-7382

9) Anbarasi M., Praveen Kumar S.,Online sales promotions of herbal products and its effectiveness towards tanisha.com,2019,Indian Journal of Public Health Research and Development,V-10,I-1,P-195-200

10) Anbarasi M., Praveen Kumar S., Various online marketing and promotions strategies to improve the validation towards the organic products in the pharmaceutical sectors,2019,Indian Journal of Public Health Research and Development,V-10,I-1,P-263-269

11) Loganathan R., Praveen Kumar S.,Grievance handling a key factor for solving issues of employees in an organization,2014,International Journal of Applied Engineering Research,V-9,I-22,P-7483-7491

12) Loganathan R., Praveen Kumar S.,Study on preference of private label brands in super and Hypermarkets,2014,International Journal of Applied Engineering Research,V-9,I-22,P-7327-7335

13) Smitha M., Praveen Kumar S.,Understanding stress and its managementamong the nurses in Chennai city,2014,International Journal of Applied Engineering Research,V-9,I-22,P-7560-7565

14) Kerinab Beenu G.H., Praveen Kumar S.,A study on the investment behavior of Chennai investors in mutual fund schemes,2014,International Journal of Applied Engineering Research,V-9,I-22,P-7520-7525

15) Loganathan R., Praveen Kumar S.,Retention strategies key for organizational productivity,2014,International Journal of Applied Engineering Research,V-9,I-22,P-7443-7447

16) Pavithra J., Ganesan M., Brindha G.,State wise analysis of microfinance sector in India,2016,International Journal of Pharmacy and Technology,V-8,I-4,P-23417-23432

17) Pavithra J., Ganesan M.,A comparative study on microfinance in India and abroad,2016,International Journal of Applied Business and Economic Research,V-14,I-8,P-5471-5476

18) Pavithra J., Ganesan M.,A study on awareness and impact of micro-financial schemes,2016,International Journal of Applied Business and Economic Research,V-14,I-8,P-5449-5460 
19) Senthilmurugan P., Pavithra J.,Consumer preference towards organised retailing with reference to Big Bazaar,2014,International Journal of Applied Engineering Research,V-9,I-22,P-7469-7475

20) Senthilmurugan P., Pavithra J.,Implication of social media marketing in growing healthcare industry,2014,International Journal of Applied Engineering Research,V-9,I-22,P-7448-7456

21) Loganathan R., Pavithra J.,Consumer perception towards private label brand over other brands in super markets and hypermarkets,2014,International Journal of Applied Engineering Research,V-9,I-22,P-7355-7360

22) Kerinab Beenu G., Pavithra J.,Tradeâ€“"off between liquidity and profitability in logistics industry,2014,International Journal of Applied Engineering Research,V-9,I-22,P-7398-7401

23) Kerinab Beenu G., Pavithra J.,A study on the prospective consumerâ€ $€^{\mathrm{TM}_{\mathrm{S}}}$ perception towards utility cars in Chennai city,2014,International Journal of Applied Engineering Research,V-9,I-22,P-7526-7531

24) Pavithra J., Dilli Babu P., Ambuli T.V.,A study on budgetary control at Maruti Service Masters, Chennai,2014,International Journal of Applied Business and Economic Research,V-12,I-2,P-151-161

25) Pavithra J., Dilli Babu P., Ambuli T.V.,A study on customer satisfaction of retro Garments Pvt Ltd, Chennai,2014,International Journal of Applied Business and Economic Research,V-12,I-2,P-381-391

26) Kerinab Beenu G.H., Pavithra J., Senthilmurugan P.,A study on the influence of promotional activities for TATA ARIA among consumers in Chennai,2014,International Journal of Applied Engineering Research,V-9,I-22,P-7572-7578

27) Vijayaragavan S.P.,An investigative expert that's general FBG sensors,International Journal of Mechanical Engineering and Technology,V-8,I-8,PP-1500-1505,Y-2017

28) Vijayaragavan S.P.,Equalization routing protocol for Wi-Fi sensor strategy,International Journal of Mechanical Engineering and Technology,V-8,I-8,PP-1662-1666,Y-2017

29) Karthik B., Kiran Kumar T.V.U., Vijayaragavan P., Bharath Kumaran E.,Design of a digital PLL using 0.35 $\hat{\mathrm{I}}^{1 / 4 \mathrm{~m}}$ CMOS technology,Middle East Journal of Scientific Research,V-18,I-12,PP-1803-1806,Y-2013

30) Kanniga E., Selvaramarathnam K., Sundararajan M.,Kandigital bike operating system,Middle - East Journal of Scientific Research, V

31) Jasmin M., Vigneshwaran T., Beulah Hemalatha S.,Design of power aware on chip embedded memory based FSM encoding in FPGA,International Journal of Applied Engineering Research,V-10,I-2,PP-4487-4496,Y-2015

32) Jasmin M.,Optimization techniques for low power VLSI circuits,Middle - East Journal of Scientific Research,V-20,I-9,PP-1082-1087,Y-2014

33) Jasmin M., Vigneswaran T.,Fuzzy controller for error control of on Chip communication,2017 International Conference on Algorithms, Methodology, Models and Applications in Emerging Technologies, ICAMMAET 2017,V-2017-January,I-,PP-1-5,Y-2017

\section{AUTHORS PROFILE}

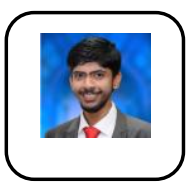

Gowtham Aashirvad Kumar, Assistant Professor, Department of Management Studies,Bharath Institute of Higher Education and Research

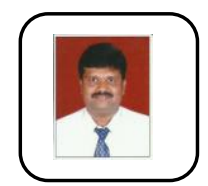

A.Ravikumar Research Scholar Department of Management Studies, Bharath Institute of Higher Education and Research

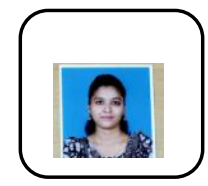

Indhumathi ,Student, Department of Management Studies,Bharath Institute of Higher Education and Research 